\title{
Quality Assurance in Higher Education. A case of legal education and training in Kenya
}

\author{
Dr. Emmily M. Sitati \\ Council of Legal Education, Kenya P.O.Box 289-00502 Karen Nairobi-Kenya
}

\begin{abstract}
Kenya just like other countries in the world has to struggle with the high demand for quality education in general and legal education in specific. More institutions of higher learning are seeking accreditation from the accreditation body (Council of Legal Education) to offer legal education yet matters of quality are least addressed. The regulatory framework of legal education in Kenya has streamlined provision of legal education and training. Today, Kenya prides herself with over 60 institutions of higher learning of which 10 are licensed to offer legal education and training. Although these institutions are still fewer in terms of meeting the demand for legal education and training, quality has been the driving force behind the licensing of legal education and training institutions. A recent audit of all universities in Kenya revealed shortfalls ininternal quality assurance policies, systems and mechanisms. This paper will discuss the growth higher education in Kenya with special emphasis to legal education and the mechanisms used in enhancing quality in legal education. In addition, the paper will explore progress made by the regulatory body in enhancing quality in legal education.
\end{abstract}

Keywords: Regulatory body, legal education and training, Quality assurance, legal framework

\section{INTRODUCTION}

In the late $80 \mathrm{~s}$ and early $90 \mathrm{~s}$, the Kenyan Government faced numerous problems including the economic recession and World Bank (WB) and International Monetary Fund (IMF) conditions. As much as this problem affected all sectors of the economy negatively, the education sector was hard hit. Kolclough and Webb, (2010) notes that lack of policy direction in Kenya contributed to high cost of education at all levels and lack of direction led to cheaper destinations. With conditionalities from the WB and IMF, the government of Kenya was forced to come up with measures to mitigate the economic difficulties the country was facing.

One such measure was the structural adjustment programme (SAPs) which saw reduction in government expenditure and introduction of user fees among others Boit \& Chepkoech, (2012). As a consequence of SAPs, user fees were introduced at the university in 1991 and students' allowances (Boom) abolished. The cost of education was to be shared between the Government and students/parents. Conversely, Universities were expected to come up with alternative ways of funding and so the birth of the self-sponsored programmes (SSP). The SSP students pay all their fees, majority are full time employees by day and students in the evening, and they seek accommodation off campus and form the majority in all the public universities, Odhiambo, (2011). On the other hand, the government sponsored (sometimes referred to as regular) students have their fees highly subsidized by the government, are full time students, are given priority when it comes to campus accommodation and their enrolment is determined by the Kenyan Universities and Colleges Central Placement Services. Scholars argue that the birth of the SSP programmes compromised the quality of education at university level. Odhiambo, (2011) discerns that students with grades as low as 'C+' are now gaining admission to competitive professional courses such asmedicine and law on parallel degree programmes. Previously, these demandingsubjects were reserved for students with grade 'A' grades.

In most universities, the twogroups (government sponsored and the self-sponsored students) are taught separately although they follow the same syllabi. In addition, lecturers are paid a monthly salary for the purposes of teaching the government sponsored students and their job group /grade determine these salaries. For the SSP programmes, lecturers are paid per hour per level and each department determines the amount to be paid based on the student enrolment. The Koech Report, (1999) argues that there is lack of 'equity, quality controland quality assurance' in the parallel programmes sacrificing academic standards.

\subsection{The growth of University Education in Kenya}

The late 1880s and early 1990s saw a rise in demand for university education and the urge by the government to increase access to university education. University education was liberalized bringing on board private and religious based providers. This was because of increase in social and individual demand for higher education, which could not be satisfied by the traditional university set-ups (Boit \& Kipkoech 2012). Before 
then, Legal education was a preserve of a few who had scored highly and the cream of the society in academic spheres. Fees for these students were highly subsidized. University education was liberalized with an aim of increasing access. Mbijiwe, et al (2014) notes that private institutions and parallel programmes within the public universities have come up to solve the problem of access. Consequently, quality was compromised and the problem has escalated with the previously preserve course registering a massive enrollment. The quality of the law graduates has deteriorated with institutions putting emphasis on quantity as opposed to quality.

Institutions of higher learning offering legal education and training have risen from two in 1980s (University of Nairobi and Moi University) to 13 (University of Nairobi- Parklands, University of Nairobi Mombasa campus, Moi, Kenyatta, Egerton, Strathmore, African Nazarene, Kabarak, Riara, Mount Kenya, Kisii, Jomo Kenyatta University of Science and Technology, Catholic University of East Africa) in 2016majority of whom are private institutions. Out of the 13 legal education and training institutions, only five institutions have validated their accreditation licenses. CLE (2017).The enrolment has also increased with a bung due to the perception that the law programme is a "graded milking cow" of these institutions. The large enrolments raise three pertinent issues.

First, the perception that high numbers will lead to a high rate of production of law graduates as well as the proliferation of law schools. This in itself is a disaster in the making as it has led to proportional deterioration of quality of legal education. The institutions have higher staff: student ratios, lack requisite physical facilities and teaching learning resources, adequate staffing and research and development. The second issue that emerges with high student enrollment is that the institutions have not proportionately invested in its infrastructure and resources to handle the increased enrolments. Odhiambo, (2011) cites that infrastructure in Kenyan public universities is in a deplorable condition with windows and doors falling apart, residential halls stinking, no subscriptions to journals, no tutorials, and that large lecture halls lack efficient microphones. In many universities, academic infrastructure can no longer cope with the number of learners, so the learners have to attend lectures in over-crowded conditions that are not conducive to effective communication and learning. The legal training and education institutions may not have their windows and doors falling apart but the infrastructure is unproportional to the student enrolment.

The proliferation of private universities with no teachers of their own has put even more pressure on public universities lecturers, who are overworked by providing services to many institutions at the same time. This scarcity has been aggravated by the brain-drain phenomenon, which has deprived institutions of their best academic assets. Universities in Kenya have lost the cream of their scholars, who have either deserted them or failed to return after completing their studies in Western countries (Oddhiambo, 2011). Finally, the market is not able to absorb all the law graduates hence the increase in professional misconduct, unethical conduct and ethical problems.

The government of Kenya has put in place a policy framework for legal education and training. This includes the Legal Education Act, 2012, the Kenya School of Law Act, 2012, the Advocate Act (Cap.16) and the Statute Law (Miscellaneous Amendment) Law 2014. In addition, the Legal Education (Accreditation and Quality Assurance) Regulations, 2016 and the Kenya School of Law regulations have been legislated.Implementation of the policy framework has met a lot of resistance from different stakeholders. In some cases, the issues have taken a political dimension leaving the regulatory body with a few choices. Issues of litigation in areas of licensing and examinations, mass failure in examinations, understaffing at the University, curriculum challenges, non- compliance are just some of the huddles the Council is dealing with. The question is can these issue be put to an end for the purpose of bringing back the lost glory of the legal profession?

\subsection{The growth of legal education in Kenya}

Legal education in Kenya traces back to pre-colonial period where the 1897 Order- in- Council was enacted to create a law society with a small group of professional, who had to come together and enhance their practice and image (Okere, 2013). The white settlers needed legal professionals to handle their legal issues and at the same time to establish their rudimentary systems of governance in the new colony and therefore made use of the solicitors who had accompanied them to Kenya. During the colonial period, Africans had limited chances to legal training due to cost implications and the fact that one had to travel to the London Inns of Court (Okere, 2013). As the need for legal services increased due to the developing Kenyan economy, Asians sent their children to India and England for legal training who upon returning to the colony worked as clerks.

Solicitors who took care of their legal needs accompanied the white settlers who came to Kenya (Okere, 2013). The first African lawyers were trained in India but were not admitted to the Bar immediately upon their return as the colonial government perceived them as ineffective. The main challenge Africans faced was lack of a local curriculum that could address the needs of the African society. The graduates were better prepared for private practice as opposed to public problem solving (Jessup, 2002). The Lord Chancellor of Great Britain set up the Denning Committee in 1961 that initiated the first legal professions to some extend 
revolutionizing legal education in Kenya. The Committee set up by Lord Kilmuir, the Lord Chancellor was tasked with the responsibility of considering facilities that were necessary for training of lawyers' in the United Kingdom to make them fit to practice in Africa (Ojwang \& Slater,1989) and consider the best model of legal training in Africa (Manteaw, 2008). Noting the gaps in the British training, the Committee recommended an additional practical training in local law and procedures in addition to the British qualification for lawyers to practice in African countries. The committee recommended that a faculty of law should be started in Tanganyika with all possible spread. The committee further recommended that the qualifications to practice in East Africa be uniform with one year of practical training be provided upon completion of degree in law programme. A school of law was to be set for this purpose in Nairobi in 1963 to produce professional advocates. These recommendations were largely adopted and have formed the basis for the common law Africa's twotiered legal education system: academic legal education in a university's law faculty for a Bachelor of Laws degree and subsequent professional legal training in a law school for admission to the bar. Additionally, the Dares-Salam school of law was established in 1961 to serve the East African bringing light to Africans especially in East African (Ndulo, 2002).

It is worth noting that the current Kenyan two-tier legal education system was greatly influenced by the Denning Committee. The Committee further recommended that legal training be university based but at the same time retained the articled clerkship programme. The Denning Committee is the first Committee to address the challenges legal education in Kenya was facing, (Gakeri, 2016). It advocated for the opening of legal practice to persons trained in local law.

In 1961, the Advocate Ordinance established Council of Legal Education (CLE) and the Law Society of Kenya and in 1963, the Kenya School of Law (KSL) was established all modeled in the English systems. Even though KSL did not have a clear mandate, nor a defined separate structure from CLE, the two institutions enjoyed a symbiotic relationship. Council was mandated to supervise KSL to ensure it provided quality legal education to persons who wished to be admitted to the Bar as recommended by the Lord Denning report. Although Council had a responsibility of vetting candidates for admission to the Roll of Advocates, it lacked regulations on provision of legal education and training by a private institution.

Kenya established its first Law programme in 1968 as a department of law within the faculty of Commerce at the University of Nairobi. The department serviced the needs of other faculties of the college in the teaching of law subjects. In 1970, the department was transformed into a faculty of law and admitted its first undergraduates in July of 1970. The initiation of the faculty of law saw the gradual phase out of the article of clerkship system at the Kenya school of law (KSL). Kenya school of Law focused on provision of post practical training for law graduates who wished to practice as advocates in Kenya Ghai, Y. \& MacAuslan, P. (2002).

Because of the tremendous growth in legal education and the overlapping functions of both the Council and KSL, there was need to streamline the status and mandate of CLE. To this end, a task force chaired by Hon. Justice A. Akiwumi was set up in 1995. The task force's mandate was to review the legal status and management of KSL. The task force recommended the re-establishment of CLE under the CLE Act (CAP 16 A) Laws of Kenya. This made CLE a cooperate body with an expanded mandate of controlling and supervising legal education in Kenya and establishing and managing KSL. The Act further enhanced the composition of the Council to include a judge of the high court, a school of law Dean, the head of the Kenya School of Law, a senior counsel appointed by the Attorney General, the permanent secretary from the ministry of higher education, and five nominees of the Law Society of Kenya. Under this Act KSL became the Council's operational agent. As a result, the functions of the two institutions became intertwined making CLE indiscernible and indecisive. The two institutions shared facilities and support services. Although the two institutions had separate management and governance, Council had a very thin staff prompting KSL to service most of CLE's operations.

A strong foundation on which the current legal framework is anchored on was delivered by the Muigai Task force, which came into place in 2005. The task force was to address the problem and confusion created by the Akiwumi task force, and segregate the mandates of the two institutions. The Muigai Task Force recommended the passage of the KSL and the LE Act of 2012. KSL was delinked from CLE in terms of its form, structure, role and functions. CLE core functions were re-designed. The regulatory and supervisory functions were separated from the training functions and policy formulation and oversight from policy consumption and implementation. Gakeri (2016) affirms that the separation of the two institutions would be more efficient in discharging their mandates.

The year 2012 saw the implementation of the Muigai task force recommendations. CLE was delinked from KSL and the enactment of Legal Education Act No. 27 of 2012 and the KSL Act No. 26 of 2012, after the Council of Legal Education Act of 2009 was repealed. These two Acts divorced the two institutions making each a separate entity. CLE mandate was redefined to regulate legal education in Kenya, license and supervise legal education providers and advice government on matters relating to legal education and training. CLE was reconstituted to exercise the functions and powers relating to setting standards for legal education providers. 
More progress was made when the Legal Education Act No. 27 of 2012 amended the LE Act Cap 16 A. Equally; KSL was re-established as a public agent of the government with a responsibility for provision of professional legal training in Kenya vide the Kenya School of Law Act No. 26 of 2012. It was mandated to train graduates to be admitted to the Bar, ensure continuous professional development, provide para-legal training, develop curricular and training modules, conduct examinations and confer academic awards among other functions.

Kenya had only two institutions offering Law degrees i.e. University of Nairobi and Moi University. Majority of Kenyans were graduating from foreign jurisdictions with an exception of the East African Community. Kenya School of Law nevertheless did not admit students from UON and Moi but the students undertook a six-month pupilage before admission to the Bar. The assumption was that these students were qualified to practice save for the practical aspect. However, there was no clear system of recognition and approval of foreign qualifications. In addition, there was a shortfall in the pupilage programme that was not structured and the requirements for both the pupil and the master were not spelt out. This influenced negatively on the quality of Advocates.

The Legal Education Act No. 27 of 2012 amended the Council of Legal Education Act Cap 16 A. The Legal Education Act makesprovision for the Regulation of Legal Education, which provided an avenue for the development of the Legal Education (Accreditation and Quality Assurance) Regulations of 2016. The 2016 Regulations were developed to address the emerging trend in legal education and training. Gakeri (2016) notes that the regulations are a comprehensive package intended to place legal education and training in Kenya on a more progressive and sustainable platform. The 2016 Regulations make provision for the licensing process, recognition and approval of foreign qualifications, quality standards and procedure for license termination, suspension and revocation of licence. CLE mandate was expanded vide the Statute Law Miscellaneous amendment Act of 2014 to include administration of professional examinations as may be prescribed under section 13 of the Advocate Act.

\section{LEGAL EDUCATION AND TRAINING PROGRAMME IN KENYA}

Kenya inherited a two-tier legal education and training system from Great Britain. The first level is the academic level and the second is the practical level. The legal education progrmme is categorized into four academic levels and a professional stage. At the academic level, the lowest level is the Certificate in Law qualification, which is a professional entry qualification for lower cadre legal support workers like clerical officers. Successful and passing of a certificate course with a credit pass qualifies a candidate for a diploma in Law programme. The Kenyan legal education and training system provides clear career path for candidate who otherwise would not have qualified for a degree programme in law by providing a clear pathway from certificate in Law, to diploma in law and finally to degree in Law.

\subsection{Certificate in Law programme}

The Council of legal education (CLE) Act 2009 does not set out the admission requirement for a Certificate in Law programme. The Legal Education Act no. 27 of 2012 provides for the Certificate programme duration to be one year of instruction but does not provide for the minimum admission requirements into the programme. The CLE Act 2009 (now repealed) provided for a Certificate qualification requirement into admission into a diploma programme. The Act allude to a credit pass in the Certificate in Law course conducted at the Kenya School of Law between the year 2000 to 2003 or any other Certificate or Diploma in a relevant field as a requirement for a diploma programme which makes it ambiguous. The Legal Education (Accreditation and Quality Assurance) Regulations 2016 sets out minimum requirement for admission to a certificate programme as follows:

1. A mean grade of C- (Minus) in the Kenya Certificate of Secondary Education (KCSE) or its equivalent with a C (plain) in English or Kiswahili.

2. At least Division III in Kenya National Certificate of Education (KNCE) Examination accompanied by evidence of work experience in the field of law of not less than five years or

3. A certificate of experiential learning issued by Council.

The CLE Act 2012 provides eleven mandatory courses to be undertaken at the certificate level. Nonetheless, the LER 2016 provide that a Certificate in Law shall require a minimum of 480 contact hours. The 2016 Regulations recommend that the courses listed for the diploma level be the same courses to be undertaken at the certificate level since they are taught as foundational courses. 


\subsection{The Diploma Programme}

The diploma programme is a two year programme (LEA 2012) and the minimum entry requirements as set out in the Legal Education Regulations 2016 are:

1. A mean grade of $\mathrm{C}$ (C plain) in the Kenya Certificate of Secondary Education (KCSE) or its equivalent with at least a C+ ( plus) in English or Kiswahili;

2. At least one principal pass at the Kenya Advanced Certificate of Education (KACE) examinations; or

3. A pass in a certificate of Law course offered at an accredited legal education provider; or

4. A certificate of experiential learning issued by the Council of legal Education.

The second schedule of the Legal Education Act 2012 further provides for eleven mandatory courses at diploma levels. These are the same courses outlined for the certificate course. They include; General Principals of Constitutional Law \& Legal Systems, Elements of Contract, Law of Torts, Criminal Law, Elements of Commercial Law, Elements of Property Law, Family Law and Succession, Elements of Business Association, Civil Procedure, Criminal Procedure, Company Law, Fundamentals of Book-keeping and Accounting and Fundamentals of Office Practice \& Management. A student who successfully completes and passes the diploma programme with a credit pass is eligible for admission into a degree programme. The Legal Education regulations 1016 require that the Diploma in Law Programme shall carry a minimum of 640 contact hours.

\subsection{The Bachelors of law (LL.B)}

The LLB programme is a four-year full time programme that prepares candidates for the advocatestraining programme (ATP). The minimum entry requirements as set out in the LE Act 2012 are as follows;a degree from a recognized university; at least two principal passes at an advanced level( Kenya Advanced Certificate of Education) or an equivalent qualification (this includes the Baccalaureate 'IB' qualification, the east African Advanced certificate of Education or the general Certificate of education. The latter is the British system of High school education where students must begin with IGCSE then proceed to GCE (A) level); a mean grade of $\mathrm{C}+$ (C plus) in Kenya Certificate of Secondary Education (KCSE); or a diploma of an institution recognized by the Commission for Higher Education and the applicant shall have obtained at least a credit pass.The LE Act 2012 is silent on the English/ Kiswahili requirement and at the same time, general on the diploma qualification. In addition, the Act sets the bar so low for the KACE qualifiers. These shortfalls are clarified in the Legal Education (accreditation and quality assurance) Regulations, 2016. English/ Kiswahili minimum requirement are set at a mean grade of B plain while the diploma requirement is specific to Diploma in Law from an accredited institution. The KACE qualification is raised to three principal passes

The LEA 2012 and the Legal Education Regulations 2016 put emphasis on the course to be offered and examined at the degree level including the core courses. Sixteen mandatory units are prescribed in the second schedule Part II of the LEA no.27 of 2012 and in the third schedule of the LER 2016. These include; Legal Research, Law of Torts, Law of Contracts, Legal Systems \& Methods, Criminal Law, Family Law \& Succession, Law of Evidence, Commercial Law, Law of Business Associations, Administrative Law, Constitutional Law, Jurisprudence, Equity \& the Law of Trusts, Property Law, Public International Law and Labour Law. The degree must be undertaken for not less than four academic years on a full time basis and six academic years on a part time/ evening basis. In addition, the Regulations require that the LLB programme carry a minimum of 1680 contact hours. There is no exception to the minimum admission requirements. However, the Council of Legal Education and the Kenya School of Law agreed on Transition Guidelines to carter for students who were already admitted to the LLB programme prior to the enactment of the Legal Education Act, 2012 and the Kenya School of Law Act, 2012. The Transition guidelines were principally aimed at preventing retrospective application of both the new Acts by providing a brief window for students admitted to the LLB programme prior to the enactment of both Acts.

\subsection{The Advocates Training Programme/ The Bar Programme.}

An LLB degree alone is not enough to qualify one to practice as a lawyer Manteau, (2008). Kenya just like many African countries have a post degree programme that prepares students for practice as advocates. The Advocates Training Programme lasts for 18 months, of which 12 months is for continuous in-house clinical training and 6 months' pupillage on a full time basis. Minimum requirements are set out in the Legal Education Act, 2012and the Legal Education Regulations 2016 as; a bachelor of law degree from an accredited university, or where applicable, a certificate of completion of a remedial programme or proof of academic progression from certificate to diploma to degree and a certificate of completion of the pre-bar examination. Mandatory courses areas outlined in the Legal Education Act, 2012 and the Legal Education Regulations 2016 are; Civil Litigation, Criminal Litigation, Probate \& administration, Legal Writing \& Drafting, Trial Advocacy, Legal Practice \& Management, Conveyancing, Professional Ethics \& Practice and Commercial Transactions. During pupillage, students are taken through an intensive hands on experience that exposes them to the nuances of legal practice. 
They are expected to work hand in hand with their Pupil Masters to ensure they acquire and enhance skills in their conduct and etiquette; advocacy; trial, conferences and negotiations; drafting, paperwork and legal research.

\subsection{Masters in Law and Doctorate programmes}

Professional advancement through career and academic progression is recognized in legal education and training as it develops capacity in different fields of law. However, the legal framework in Kenya is not specific on the minimum entry requirements for both the Masters and doctorate in law programmes. Legal Education Act 2012 is more specific on the certificate, diploma and degree levels. The Legal Education Regulations, 2016 set out minimum entry requirements for admission into the master's degree in law programme in the third schedule. The LLM programme takes a minimum of one and a half years with a minimum of 630 contact hours. For admission into the LLM programme, the candidates must satisfy the minimum requirements for the admission to an undergraduate programme in law. In addition, he/she must possess a degree in law (second-class upper division from a recognized university or a degree in law (secondclass lower division) from a recognized university with a minimum working experience of three years. No mandatory courses are prescribed but institutions may choose a line of specialization.

The duration for a doctorate programme as set out in the legal Education Regulations is a minimum of three years. The Regulations are also flexible on the minimum entry requirements for admission to the doctorate programme in law. The LER, 2016 set the minimum requirement to for admission to a doctorate programme in law as a master's degree from a recognized university. This is the only requirement into the Doctorate programme. Interestingly, the master's degree is not restricted to law. Legal training institutions are given a leeway to set admission requirements over and above those prescribed as appropriate provided they are consistent with the LER, 2016. Admissions based on experiential learning are not valid if the person has not been issued with a certificate of experiential learning by CLE. The courses are not prescribed and training institutions are at liberty to structure their programmes in line with their niche areas and the institutional philosophy.

\section{QUALITY ASSURANCE, COMPLIANCE AND LICENSING}

Section 8 (2) of the LE Act, 2012 gives Council powers toset and enforce standards in accreditation, curriculum, mode of instructions, examinations, and monitoring and evaluation of legal education providers. Legal Education (Accreditation and Quality Assurance) Regulations of 2016 are the subsidiary legislation of the Legal Education Act of 2012. They are an improvement of the Council of Legal Education (Accreditation of Legal Education Institutions) Regulations of 2009. These Regulations are saved by Section 49 of the Legal Education Act No. 27 of 2012 under the Savings and transitional arrangements. These Regulations are a pillar on which the Council discharges its mandate.

Section 8 (1) of the LEA 2012 provides for the functions of the Council as follows; Regulate Legal Education and training in Kenya offered by legal education providers, License legal education providers, Supervise legal education providers, Advise Government on matters relating to legal education and training, Recognize and approve qualifications obtained outside Kenya for purposes of admission to the Roll and Administer such professional examinations as may be prescribed under Section 13 of the Advocates Act Cap. 16.

Section 8 (2) mandates Council to set and enforce standards relating to the Accreditation of legal education providers for the purpose of licensing. Legal education (accreditation of legal education institutions) Regulations 2009, which were provided for by the Council of Legal Education Act 2009 (now repealed by the Legal Education Act 2012) provision for accreditation Process in Part II, Legal Education Training in Part III and Appeals and Adhoc Training in Part IV.

The Legal Education (Accreditation and Quality Assurance) Regulations, 2016 make provision for; The Licensing Process which includes application for accreditation, inspection, accreditation and issuance of license. The regulations also provide procedures for renewal of license in Part II while Part V provides regulation for termination, suspension and revocation of a license. Part III outlines the quality Standards to be met by legal education and training institutions. These are set out in the third schedule of the LER, 2016training and Termination, Suspension and Revocation of License. The main role of universities is to equip students with advanced skills useful in the workplace and to further human knowledge and understanding of the world. This includes both practical and theoretical skills that require adequate manpower to actualize.

Universities play an important role in national development. They s are perceived to provide relevant and quality education and produce highly trained, skilled and competent human capital that can drive the economy and enable the county achieve vision 2030. University education is supposed to prepare the country's workforce to meet the needs of the society. As such, the quality of education should be credible, relevant and accessible. Eshiwani (2009) and Mutisya (2010) noted that the quality of education in Kenyan universities has 
been watered down by among other reasons missing marks, sexually transmitted grades and commercially acquired term papers, project papers and thesis. Birungi (2006) points out that student assessment is an important element of quality assurance for the regulatory agencies and for individual universities. However, quality in public universities is affected by inadequate invigilation and supervision of examinations. The issue of lack of control measures against exam cheating and detection mechanisms is yet to be addressed Gudo, (2011). The missing marks syndrom is infectious especially in public universities. Students jam corridors looking for course lecturers to provide the missing marks. One wonders if there are clear regulations governing examinations and how marks for some students go missing and not others.

Academic corruption has put universities in danger with serious repercussions on quality, access and equity in education Hallak and Poisson, (2002). One such form of academic corruption is influencing the score by providing incentives to the lecturers in form cash, sex or property for students who are from well to do families. Ondicho (2015) attributes proliferation of universities and massive enrolment coupled with inadequate resources and facilities as the contributors to the diminishing quality of university education. The issue of demand that is anchored in the government policy of increasing access and the perceived economic benefits by individuals of University education has impacted negatively on quality of education. Looking at the current situation, demand for university education has outpaced supply. Various studies (Calleb O, et al 2011, Cheboi 2006 and RoK, 2006 ) isolate shortage of facilities and resources, information technology and research as major contributors to poor quality of university education. For example, a study by Gudo et al (2011) on university expansion in Kenya and issues of quality revealed that effective teaching and learning in public universities is hampered by lack of enough lecture rooms, forcing students to attend lectures while standing outside the lecture rooms.

The challenge of facilities and resources are not unique to one institution or country but it is cross cutting among institutions and countries. Okwakol (2008) asserts that most African Universities do not have adequate physical facilities such as lecture rooms, offices, library and laboratory space to provide a suitable learning and teaching environment. Nathui (2007) links lack of adequate reading resources to poor reading culture.

With the massive expansion of university education coupled with increase in student enrolment both on regular and part time basis, there has been high demand for qualified lecturers. The rate at which universities are producing qualified graduates at a doctorate level does not commensurate the current demand. This affects the quality of education as the current lecturers are overworked, with high workload affecting the quality of research (Olel, 2006, Ngolovoi 2006). At the same time, universities are forced to hire lecturers who lack requisite competencies. Massification generates access to higher education, but it also increases public concern over the quality of education and student outcomes. As a result, it poses several challenges to quality assurance and management in higher education. Hou, A.Y., Ince, M., Tsai, S. et al. (2015). The challenge of mismatch of competencies and teaching units has been very common in most universities. This tickles down to the quality of research carried out in the universities. Odebero (2010) observes that master's students are forced to do a project which does not go through the quality assurance checks as compared to a thesis which is more vigorous. Nangili (2015) points out areas of concerns in providing quality education in the university as; brain drain and brain gain, thirst for university degrees, intellectual bankruptcy in terms of moonlighting and sun lighting and negative attributes of information communication technology

The Commission for University Education (CUE 2010) has provided guidelines on lecturer student ratios as follows: Applied sciences 1:10, Arts and Humanities 1:15, Medicine and applied Sciences 1:7, Pure and natural sciences; 1:10 and Social sciences1; 18. The ratios were set based on the specific nature and requirements of courses. Courses that are practical oriented have lower lecturer student ratios than those that are more theoretical.

For universities to assure quality, there is need for both internal and external quality assurance mechanisms to be put in place. The Commission for University education has established quality assurance units in all universities in Kenya. Nonetheless, the functionality of these units is debatable. Nangili (2015) asserts that quality is the responsibility of respective universities, as such the universities are required to develop and implement effective policies and mechanisms for self-regulation. This enhances development of institutional quality culture. The World trade organization declared education as a tradable good. As such, there is commercialization of university education with more satellite campuses and learning centers opened as opposed to knowledge creation, talent development, creativity, production, innovation and patents.

\subsection{Quality as a priority by Council of Legal education.}

Council of legal Education (CLE) is a statutory body established by the Legal Education Act no. 27 of 2012 (RoK 2012) with the mandate of regulating, supervising and licensing legal education programmes and providers in Kenya. The Statutes Law (Miscellaneous Amendment) Act 2014 extended councils mandate to include recognition and approval of qualifications obtained outside Kenya for purposes of admission into the 
Roll of Advocates and to administer such professional examinations as may be prescribed under section 13 of the advocate Act. Specific functions of CLE are;

a) Regulate legal education and training in Kenya;

b) License legal education providers;

c) Supervise legal education providers;

d) Advise Government on matters relating to legal education and training;

e) Set standards for accrediting legal education providers;

f) Set standards for curriculum and modular instructions;

g) Set standards for the mode and quality of examinations;

h) Set standards for harmonization of Legal Education Programmes in Kenya and the Region;

i) Monitor and evaluate legal education providers and programmes.

j) Conduct Bar examinations

k) Recognize and equate foreign qualifications

In her quest to discharge this mandate, Council has put in place systems and structures which are geared towards overseeing the institutional programmes and ensuring that quality is adhered to. This include a fully-fledged department that deals with issues of quality assurance, compliance and Licensing. A director who reports to the CEO heads the department. The directorate is further divided into two sections; Quality, compliance and licensing section and standards and curriculum development section. The Legal Education (Accreditation and Quality Assurance) Regulations 2016 set out the quality standards to be satisfied by legal education institutions for purposes of accreditation and quality assurance. For an institution to provide legal education and training in Kenya, it must be accredited by Commission for University Education and licensed by CLE. Licensing provides public recognition and institutional confidence, legitimizing the programme.

Council considers quality an important ingredient of her mandate. (Martin and Stella 2007) points out that as quality assurance guardians of higher education, quality assurance agencies are required to guarantee "the credibility of the review process and to ensure the objectivities and transparency of their decisions or recommendation". The Commission for University Education and other regulators carry out occasional audits to ensure that institutions have clearly defined internal quality monitoring procedures linked to effective action implementation. Hou et al, (2015). Audits evaluate more of the process rather than quality. In assuring quality in legal education and training institutions, Council uses two main approaches.

1. Standards based approach. Council has set standards institutions are expected to comply with in terms of institutional management, curriculum development and implementation, teaching and learning resources and facilities. Integrating ICT in curriculum management is a key component in ensuring that the law programme is not domesticated but diversified. Institutions are expected to conform to this predetermined criteria. The criteria is documented in the Legal education (Accreditation and Quality Assurance) Regulations, 2016 and well stipulated in the Council of legal Education Act 2012.

2. Fitness for purpose approach. In this approach, institution have to live by their philosophy, set objectives and address the needs of the society. Council ensures that institutions have clear mechanisms in place for achieving the set objectives. In the preliminaries, institutions have to justify the need for the programme and the specific areas the programme is to address. In addition, clarity on the uniqueness of the programme is paramount (institutional niche area). Stakeholders' engagement in identifying the niche is important. This is evaluated by council through a feasibility study report.

Both internal and external quality assurance helps Council in decision-making processes. The Council of legal education assures quality at two levels. First, legal education and training institutions are expected to develop an internal quality assurance mechanism for self-assessment. The main challenge here has been lack/inadequate quality assurance mechanisms in legal education and training institutions and inadequate skilled man-power. However, any successful internal quality assurance implementation should heavily rely on the quality of staff. There is need for institutions to invest in staff training. Consequently, implementation of internal and external quality assurance is face with a myriad of challenges as stated by Hou, (2015). Some of these challenges include, lack of transparency of internal quality assurance activities, inadequate publications of internal annual, self-review and other relevant quality assurance reports. In addition, stakeholders are left in the dark on the internal review outcomes and there is no forum for stakeholders to air their views. Other challenges are lack time and resources for internal quality assurance implementation, difficulty in setting criteria and benchmarks for quality assurance and budgetary constraints. Senccila (2013) notes that external quality assurances focus on outcomes achieved by higher education institutions rather that processes and it is control oriented. If institutions have stronger internal quality assurance mechanisms, then there is less need for external quality assurance measures. Council then conducts an external review at the institutional and program levels. This stage is in two tiers, where the institutions programme and facilities are audited for compliance and the 
programme peer reviewed. If approved fit, then an inspection is carried out by the sub- committee of the Council in charge of quality assurance, compliance and standards.

\subsubsection{Quality assurance tools}

Both the legal framework and the internal tools are used. These includes;

- $\quad$ The Legal education Act no. 27 of 2012

- $\quad$ The University education Act 2012

- $\quad$ The Legal Education (Accreditation and Quality Assurance) Regulations 2016.

- CLE Strategic Plan 2014-1018

- Inspection parameters

- Quality assurance manual (revised in 2016)

\subsection{Quality in curriculum development and implementation}

Quality is measured by the kind of input into the university system and whether the input (students) satisfy appropriate entry requirements. Indicators of quality as cited by Hou (2015) include; documents that guide the study process like study plans, syllabi and timetables. These documentsshould meet a certain threshold. Other indicators are sufficiently qualified teaching staff, study process of an appropriate technical and methodical level, reliable students' knowledge and skills control and clearly defined management responsibility and sufficient competence for implementation of necessary changes.

These factors form the basis on which quality curriculum is delivered. A quality curriculum should take into consideration the emerging needs of the society and the rationale of the programme should bewell grounded. In this case, stakeholder's involvement in curriculum development through need assessment/ feasibility study is paramount. Stakeholders help ensure that the curriculum has meaning (Hipkins, R., Cowie, B., Boyd, S., Keown, P. and McGee, C. 2011) and it is addressing the changing needs of the society. Both internal stakeholders (students and teachers) and external stakeholders (practitioners, private sector and employers) should be involved. A feasibility study divulges the gaps in the curriculum that need to be filed and the study findings informs the programme development. Stakeholders identify the programme niche and the niche area is trickled down the whole curriculum to give it its zest and distinguish it from other programmes. The curriculum is then prepared in line with the general rules and regulations as set out in the third schedule of the Legal Education (Accreditation and Quality Assurance) Regulations, 2016.

Peer review of the curriculum by the legal experts and curriculum development experts is an important stage. For purposes of objectivity in making a determination on the outcome of the reviewer's comments, three peer reviewers are selected with no conflict of interest. The institutions then move to the next stage of preparing curriculum delivery materials such as course outlines, teaching timetables, teaching notes, and determining the appropriate pedagogy for each topic. This should take into account technological changes and the need to make learning more interesting (discovery and learner centered strategies as opposed to expository and teacher centered strategies).

Given that societal needs are not static, the regulations stipulate that a legal education programme must be reviewed after every five years. The social reconstruction theory argues that a curriculum should adapt to the social, economic and political issues and identify and solve societal problems which change from time to time McNay (2009). A legal education and training programme at degree level takes four years By the end of four years, new needs have arisen, and gaps in the curriculum identified thus justifying the four year period for curriculum review. A teacher plays a key role in curriculum implementation. Teachers are the major pillars in the teaching and learning process. The quality of teachers explains the differences in the learning outcomes. As such, teachers should poses specific competencies that will facilitate proper delivery of the curriculum. Staff recruitment, development, promotion and motivation should be done carefully to ensure that the right staff for the job are engaged and retained. This includes their level of professional training, specific skills (areas of specialization) and how the skills are marched with teaching units, continuous professional development, and engagement in research and publication. Council of Legal education provides regulations on qualification of lectures who wish to teach at different levels such as bachelors, masters and Ph.D. Incorporation of adjunct and visiting lecturers in the programme is an important aspect of ensuring that gaps in the skills are filled and that expertise in specific fields are made use of.

The world is moving fast and there is a paradigm shift from teacher centered to learner-centered strategies. In addition, there is increase in use of information communication technology making education not just a delivery of facts and information but an educative process of cultivating all the abilities (cognitive, psychomotor, affective, and intellectual) of the learner. This therefore calls for integration of ICT in curriculum process. Overhead projectors, laptops, video conferencing, iPad, Tablets and smartphones are currently very common. The challenge of part timing and moon lighting is not special to specific institutions. It is a worldwide crisis. Sigwalt (1970) asserts that part time market is perceived to be cost effective and especially when 
enrollment exceeds the current capacity. Part timing does not unionize or cause tenure hustles. This is best if done on skill based to fill the skill gaps. However, in most cases as observes Sigwatt (1977), hiring of part-time is based on the impression made on the division head like the dean or head of department or the recruiting officers. Some institutions have engaged more part time lectures than full time lecturers posing a challenge to programme implementation.

Other challenges include; Large proportions of part time students who overwhelm the capacity of institutions in terms of human resources, physical infrastructure and teaching learning resources. There is also the impact of globalization, which has affected the manner in which knowledge is disseminated. Privatization and liberalization of education sector has seen mushrooming of many universities and scholars with little commitment to knowledge. In addition there is a rigid administration criteria that does not allow credit transfers between universities and other post-secondary institutions. This has further made education in the higher levels seem like it is locked within its boundaries. Tribalism has hindered quality performance in universities. In addition, there has been massive proliferation of foreign qualifications in the country.

\subsection{Quality in recognition and approval of foreign qualifications}

Recognition and approval of foreign qualifications means the legal and regulatory framework as well as the processes and procedures by which the Council of Legal Education makes determinations on applications for recognition of foreign qualifications in Law for purposes of admission to the Roll of Advocates in Kenya. Section 8(1)(e) of the Legal Education Act, 2012, paragraph 18 of the CLE (Accreditation) Regulations, 2009, the Statute Law (Miscellaneous Amendment) Act, 2014 as well as the Legal Education (Accreditation and Quality assurance) Regulations 2016 provide the legal and regulatory basis by which the Council recognizes and approves foreign qualifications in law. However, where the quality standards of a foreign legal education provider in which the qualification is acquired does not satisfy the quality standards set out in the third schedule to the Legal education (accreditation and Quality Assurance) Regulations, 2016, the recognition is declined. This is attributed to the fact that Council has put in place systems and structures that ensure there is a level playground for all the players from both local and international universities.

The criteria for recognition and approval is set out in the Legal education (accreditation and Quality Assurance) Regulations, 2016. A copy of a curriculum being equated is evaluated in terms of the lecture hours, the units taught and the content. Accreditation status of the institution in which the degree was awarded is also established. The process of recognition and approval is therefore distinctive in the sense that qualifications submitted for recognition and approval are so diverse in terms of institutions of origin, media of instruction, curriculum covered, programme nomenclature (LLB, Bachelors of arts in Law,), mode of study, course outline, structure and course contents. Several scenarios come to face during this process of recognition and approval of foreign qualification. Some qualifications are obtained in other languages rather than English. Equation of foreign qualifications obtained in a language other than English requires translation. Council is therefore forced to assess the extent to which the said qualifications are equivalent to the Kenyan prescribed requirements in terms of both the courses covered, the content and the relevance of the programme to the local market. This may be a challenge given that Council may have limited capacity to assess such qualifications. Council requires that law degrees be taught in English in order to entertain and assess an equation application for purposes of entry into the Kenyan legal market. Related to this challenge are applicants, who undertook part or full degree in a language other than English, Council requires evidence of English proficiency. However, Council does not accept TOEFL or IELTS qualifications. Council presently accepts a certificate of English Proficiency offered at a local institution, which is approved by the KNEC. The challenge here is that this practice conflicts with international admissions practices in many jurisdictions worldwide where TOEFL and IELTS are accepted as proof of proficiency in the English language. Furthermore, there is no formal documented Council position on this issue.

Council requires that students who do not meet the threshold for recognition and approval of their qualification undertake a remedial programme. Currently, only one (1) institution, Riara University, is accredited by Council to offer the remedial programme. Similarly, only one (1) institution, i.e. KSL provides the ATP Programme. In both of these cases, it is not by design, intention nor is it as a result of any alleged tacit collusion between Council and any of the said Institutions to create some kind of monopoly. The recent judgement in J.R. 377 of 2015,Nabulime Miriam \& Others vs CLE, found it untenable to have only one institution as the sole provider of the remedial programme. Indeed Council has invited all licensed legal education providers to express their interest to offer the remedial programme and/or the ATP.

Council currently has a procedure for recognizing foreign LL.B Degree qualifications but does not have a regulatory framework as well as procedures for recognition and approval of foreign Diplomas in Law qualification, Masters (LL.M) Degrees in Law or PhD programmes. However, recognition and equation of LL.Ms and Ph.Ds are within Council's mandate. Council has maintained that Bachelors of Arts in Law Degrees are not recognized nor approved by Council. Students present such qualifications for recognition and approval 
posing a challenge. Equally, Council requires any applicant with foreign high school Ordinary $(\mathrm{O})$ level and/or Advanced (A) level qualifications to obtain KNEC equation. Long delays by KNEC in equating foreign $\mathrm{O}$ and A level high school qualifications has been experienced which in turn impacts upon the Council's turnover times for determining equation applications for applicants with foreign high-school qualifications.The implication is that graduates with these qualifications penetrate into the Kenyan law market irrespective of the quality of their qualification posing a challenge to the regulator. There are possibilities of the regulators being accused of applying double standards.

Although neither the LEA, 2012 nor the CLE Regulations, 2016 explicitly provide against nonrecognition of law degree qualifications obtained through open and distance education learning (ODeL), Council has taken the position that such qualifications are not recognized. Council has on various occasions declined to recognize and approve LL.B Degrees obtained through Open \& Distance Learning platforms not previously vetted and approved for purposes of the Advocates Training Programme. This has left a few students who possess law degree qualifications obtained through ODL 'locked out' as it were from proceeding with the legal studies in Kenya to wit admission to the ATP. The background to this decision is that the operative regulatory framework requires legal education providers to invest enormous resources in academic staff, library, physical infrastructure, internet, student support services including mentorship, mooting and long term planning. Investments which are largely absent in ODL based learning. In terms of contact hours, the LL.B Degree requires at least 1680 contact hours. Council has been aware that distance-learning programmes have no local or international mooting, group discussion, oral presentations, guest speakers or any form of attachment, which are emblematic of full time study.

Council is not against ODL per se as a learning platform, but rather Council does not equate law qualifications obtained through ODeL as it is not satisfied that such qualifications subject candidates to the rigors characteristic of legal training nor do they inculcate the requisite skills, values and attitudes critical in legal training. Nonetheless, Council does not have any policy/ regulations/ standards against which to measure ODeL qualifications. This means that Council does not have any justifiable basis to defend its position on ODeL qualifications, which exposes Council's decisions relating to ODeL law qualifications to the risk of lack of legal defensibility. Open and Distance Learning as a learning platform is not new. However, it is a relatively new concept as a learning mode for the law degree studies. Lack of understanding of ODeL cannot be ruled out. There is need for a comprehensive study to be undertaken by Council to evaluate the propriety of ODeL as a platform for obtaining qualifications in Law. Research results from this study could form the basis for benchmarking and lead to establishing criteria on which to assess ODeL qualifications.

\subsection{Quality in content delivery}

Most African countries do not have clearly defined policies on open and distance education learning. With the exception of South Africa, few African countries have clearly defined national policies to guide the development of distance education in their respective countries. The absence of such policies is a clear obstacle to the development of distance education. Open and distance learning (ODeL) is becoming an indispensable part of the mainstream educational platforms in both developed and developing countries, with particular emphasis in the latter (UNESCO, 2002).

Although ODeL is gaining prominence in Africa, there are challenges to be addressed to ensure effectiveness of implementation. Technological constraints hinder implementation of ODeL programmes. Infrastructure outside of major cities remain inadequate. Connectivity beyond major capital cities and untrained personnel poses a potential problem in creating a national distance education strategy. A study conducted in Zimbabwe showed that a majority of the lecturers $(97.5 \%)$ facilitating ODeL have no experience in distance education (Mpofu et al., 2012). A National Education Association (NEA) survey in the United States reported that teaching staff members' top concern about distance education was the argument that the progamme was not cost effective in terms of the teachers input.

The idea of open and distance learning (ODeL) was a well thought out idea as an alternative mode of programme delivery aimed at enhancing access to university education. However, although many nations in the world have embraced the concept, various stakeholders like the Council of Legal Education have raised concerns about quality. Study findings on the effectiveness of ODeL reveals that educational output is not dependent on the mode of delivery or learning environment and that students in distance learning programme perform as well or better on assignment, class activities, and examinations when compared to campus based students ( McCaan, 2006 \& LaPorte, 2008). Council does not recognize ODeL qualifications and therefore graduates who poses this kind of qualification are barred entry into the Advocates Training Programme offered by the Kenya School of Law. The Legal Education Act, 2012 and the 2016 Regulations explicitly provide against non-recognition of law degree qualifications obtained through ODL, Council has taken the position that such qualifications are not recognized. This has thrown a number of students in confusion. In addition, Council does not have any policy/ regulations/ standards against which to measure ODeL qualifications. Regulation 45 
clearly states that a legal education provider may award a qualification for a course conducted through online or distance learning if the programme has been accredited by the Council of Legal education. The assumption is that Council has capacity to accredit such programmes and recognize the ODeL qualification. Therefore, Council does not have any justifiable basis to defend its position on ODeL qualifications.

\section{CONCLUSIONS}

Demand for legal education has been greatly influenced by the need to develop capacity in the legal sector. It is perceived that the rates of return for legal practitioners are higher that other social sciences, business administration and humanities. However, the supply has not commensurated with the resources available resulting to quality issues. The regulatory authorities have developed common regulations and requirements to guide provision of legal education and training. Implementation of these regulations is faced with a myriad of challenges including litigations, non-compliances and political interference. Issues of inadequate teaching and learning resources, high faculty- student ratios, understaffing and moonlighting of faculties in more than two universities, dysfunctional institutions and inadequate research require urgent attention. Stakeholders have mixed opinions on the legal framework guiding provision of legal education. Without stakeholders support, quality will always be compromised raising questions about the output of the programme. Political goodwill is vital and consistency in implementation key.

\section{REFERENCES.}

[1] Abdalla U. A. (2016).Motionless Points in Chaos: Education Reforms, Innovations and the Challenges for Higher Education in Nigeria, A review in Africa -Asia University for educational development Report of the international Experience sharing Seminar (10. Efforts towards improving the quality of education, Department of Education Bayero University, Kano, Nigeria.

[2] Altbach, P. J., \& Knight, J. (2007). Internationalization of Higher Education: Motivations and Realities.Journal of Studies in International Education. 11(3-4), 290-305.

[3] Birungi, P. (2006). Quality Assurance in East Africa: The State of the Art.The Uganda Higher Education Review.Journal of the Council for Higher Education, 3 (2), 10-16.

[4] Boit, J., M. \& Kipkoech, L., C. (2012). Liberalization of higher education in Kenya: Challenges and prospects. International Journal of Academic Research in Progressive Education and Development, 1( 2), pp 33-41.

[5] Cheboi, B. (2006).Funding Patterns and their Effects on Quality of Higher Education in Kenya. A conference paper presented at Kenyatta University on $6^{\text {th }}$ November 2006. Nairobi.

[6] Eshiwani, G. (2009). University Expansion in Eastern Africa: Challenges and Options in Higher Education. Inter-University Council for East Africa (IUCEA), Newsletter Vol. 39 pp 17-22.

[7] Gakeri, J.K. (2016). Enhancing Legal education in East Africa: Contextualizing the role of legislative, CLE and Judiciary in Kenya. International Journal of Humanities and Social Sciences . 6, (4), 61-74

[8] Hallak, J., and Poisson, M. (2007). Corrupt schools, corrupt universities: What can be done? International Institute for Educational Planning, Paris.

[9] Hipkins, R., Cowie, B., Boyd, S., Keown, P. and McGee, C. (2001).Curriculum Implementation Exploratory Studies 2, Report to the Ministry of Education. New Zealand Council for Educational Research: New Zealand.

[10] Hou, A.Y., Ince, M., Tsai, S. et al. (2015). Quality assurance of quality assurance agencies from an Asian perspective: regulation, autonomy and accountability. Asia Pacific Educ. Rev. 16: 95. doi:10.1007/s12564-015-9358-9

[11] Hughes, J. C. (2008). Curriculum development in higher education: Faculty-driven Processes and practices. Jossey-Bass, San Francisco: Accessed on 20/2/2017 from http://eu.wiley.com/WileyCDA/WileyTitle/productCd-047027851X.html

[12] Hughes, R. (1994). Legitimation, higher education, and the post-colonial state: A comparative study of India and Kenya. Comparative Education. 30, (3), 193-204

[13] Jessup,G. (2002). Symbiotic Relations: Clinical methodology. Fostering New Paradigms in

[14] African Legal Education. Clinical Law review 377

[15] Manteaw S.O. (2008), Legal Education in Africa: What type of lawyers does Africa need?

[16] University of Pacific McGeorge School of Law, Accessed on 20/2/2017 from http://www.mcgeorge.edu/Documents/Publications/02_Manteaw_MasterMLR39.pdf.

[17] Martin, M., \& Stella, A. (2007). External quality assurance in higher education: making choices. UNESCO: Paris.

[18] McCann B. M. (2006), "The relationship between learning styles, learning environments, and student success, Journal of Agricultural Education, 47, ( 3) 
[19] McNay, M. (2009).Western Guide to Curriculum Review, University of Western Ontario Teaching support Centre, Canada.

[20] Ministry of Education (MoE) (2012).Towards a globally competitive quality education for sustainable development," Author, Nairobi.

[21] Mutisya, K. (2010). How the wrong policies turned public universities into cacophonous markets. Daily Nation newspaper, 22rd December, 2010 p.13.

[22] Ndethiu, S.N. (2007). The Role of Kenyatta University in Promoting Good Reading Habits among Undergraduate Students. Unpublished PhD Thesis, Kenyatta University, Nairobi.

[23] Ndulo M. (2014). Legal Education in Africa in the era of globalization and the Challenge of Development. Cornell Law Faculty Publications. Paper 987 accessed on 22rd January 2017from http://scholarship.law.cornell.edu/facpub/987

[24] Ngolovoi, M. (2006). Means Testing of Student Loans in Kenya. Presented at the Comparative and International Higher Education Policy: Issues and Analysis Workshop, University of Albany.

[25] Nyerere, J., Gravenir, F., and Mse, G. (2012). Delivery of open, distance, and e learning in Kenya. The International Review of Research In Open And Distributed Learning, 13(3), 185-205. doi:http://dx.doi.org/10.19173/irrodl.v13i3.1120

[26] Odebero, S.O. (2010). Crisis in Financing and Management of Kenyan Higher Education: Implications for Planning Reform agenda. Paper presented at Educational Management Society of Kenya Conference held at Migori Teachers"e College, 12th -14th April.

[27] Odhiambo, G., O. (2011). Higher education quality in Kenya: a critical reflection of key challenges. Quality in Higher Education, 17, (3), 299-315. DOI: 10.1080/13538322.2011.614472

[28] Ojwang J. B. \& Salter D.R. (1989). Legal Education in Kenya Journal of African, 33, 82-96

[29] Okoth O. (2013).The legal Education in Kenya, A historical Analysis. Down loaded on $9^{\text {th }}$ November 2016 from https://www.academia.edu/11300374/ the legal education in Kenya

[30] Okwakol, M.J.N. (2008). Challenges and Prospects for Quality Assurance in Science and Technology Education in African Countries, The Uganda Higher Education Review, Journal of the National Council for Higher Education, 5 (2), 17-26.

[31] Olel, M. A. (2006).The Effect of Privately Sponsored Students Programme on Efficiency and Equity in Public Universities in Kenya and Uganda.Unpublished PhD Thesis, Maseno University.

[32] Sigwalt R. (1977). The Part-time Game.Journal of Opinion, 7 (3), 22-24

[33] Sun, P. (2010). China's efforts for promoting research integrity. Professional Ethics Report, 13 (4), 1-3.

[34] Trow, M. (2000). From Mass Higher Education to Universal Access: The American Advantage. Research and Occasional Paper Series, Center for Studies in Higher Education: UC Berkeley.

[35] UNESCO. (2002). Open and distance learning: Trends, policy and strategy consideration. Retrieved on $1^{\text {st }}$ January 2017fromunesdoc.unesco.org/images/0012/001284/128463e.pdf.

[36] Viktoras Senčila (2013). Internal Quality Assurance \& External Quality Assurance: what comes first, with which indicators and how do we involve stakeholders? Lithuanian experience in Internal Quality Assurance. EURASHE Seminar, Bucharest.

[37] Vroeijenstijn, T. (2008). Internal and external quality assurance-Why are they two sides of the same coin? Retrieved January $15^{\text {th }}, 2017$, from http://www.eahep.org/web/images/Bangkok/28 panel ton.pdf.

[38] Wolf, P. (2007). A model for facilitating curriculum development in higher education: A faculty- driven, data-informed, and educational developer-supported approach, In P. Wolf, P. \& Hughes, J.

[39] Status

[40] Legal Education (Accreditation and Quality Assurance) Regulations, 2016

[41] Legal Education Act No 27 of 2012

[42] The Kenya School of Law Act No. 26 of 2012

[43] Legal Notice No. 170 of 1997

[44] Legal Notice No 357of 1997

[45] Reports

[46] Denning Committee report (1961). Report of the Committee on Legal Education for Students from Africa.

[47] Mungai Task Force Report (2005). Task Force on Development of a Policy and Legal framework for Legal Education in Kenya: Nairobi. Government printers.

[48] Task Force on Development of Policy and Legal framework for Legal Education in Kenya (1995).

[49] The Koech Report, (1999). 'Kenya Commission of Inquiry into Education in Kenya, totally integrated quality education and training (TIQET)'. 